$\begin{array}{llllllllllll}\text { I I I . } & \text { W } & \text { S } & \text { P } & \text { O } & \text { M } & \text { N } & \text { I } & \text { E } & \text { N } & \text { I } & \text { A }\end{array}$

\title{
Tadeusz, Kornaś
}

Uniwersytet Jagielloński w Krakowie

\section{W GABINECIE I NA WYPRAWIE Moje wspomnienie o Zbigniewie Osińskim (1939-2018)}

Pisanie o Zbigniewie Osińskim jest niebywale trudne. Bo kryło się w tej jednej postaci wiele tajemnic. Gabinetowy badacz, spędzający godziny w archiwach, który potrafił wziąć plecak i wyruszyć na przysłowiowy koniec świata, by badać swój ulubiony teatr i spotykać się z ludźmi. Wymagający i bezwzględny erudyta, który oczekiwał od studentów i naukowców tak wiele, że aż paraliżowało to niektórych, a z drugiej strony uczestnik działań parateatralnych Grotowskiego czy Wypraw Staniewskiego, gdy tę profesorską twarz trzeba było przysposobić do zupełnie innej rzeczywistości, w której przychodziło się spotykać na równych prawach z ludźmi prostymi. Zapewne w niektórych sytuacjach czuł się lepiej, $\mathrm{w}$ innych gorzej, jednak pasja poznawania, traktowanie swojego życia w kategoriach misji - to było dla niego najważniejsze. Można powiedzieć, że był wzorem naukowca - i chyba spełniał się w tym posłannictwie.

Pochodził z Poznania i tutaj rozpoczął studia na polonistyce. Zbigniew Osiński wyszedł ze szkoły profesora Zygmunta Szweykowskiego i do końca życia uważał tę postać za swój największy naukowy autorytet. Pozornie trudno o większy kontrast - Szweykowski był specjalistą od Prusa, Sienkiewicza, zaś Osiński zajmie się nowoczesnym teatrem. Jednak to od Szweykowskiego Osiński uczy się warsztatu badacza literaturoznawcy i rzetelność pozostanie jego znakiem firmowym. Osiński był ostatnim doktorantem Szweykowskiego. W 1966 obronił rozprawę „Inscenizacja dramatów Wyspiańskiego w teatrze lwowskim Wilama Horzycy 1932-1937'. ${ }^{1}$ Pracował później jako adiunkt na Uniwersytecie Poznańskim.

1.

Zbigniew Osiński po raz pierwszy widział spektakle Jerzego Grotowskiego (Orfeusz i Faust) w Poznaniu, lecz, jak wspomina, nie wzbudziły w nim zachwytu.

1 Promotorem rozprawy był Zygmunt Szweykowski, recenzentami Zbigniew Raszewski i Jerzy Ziomek. 


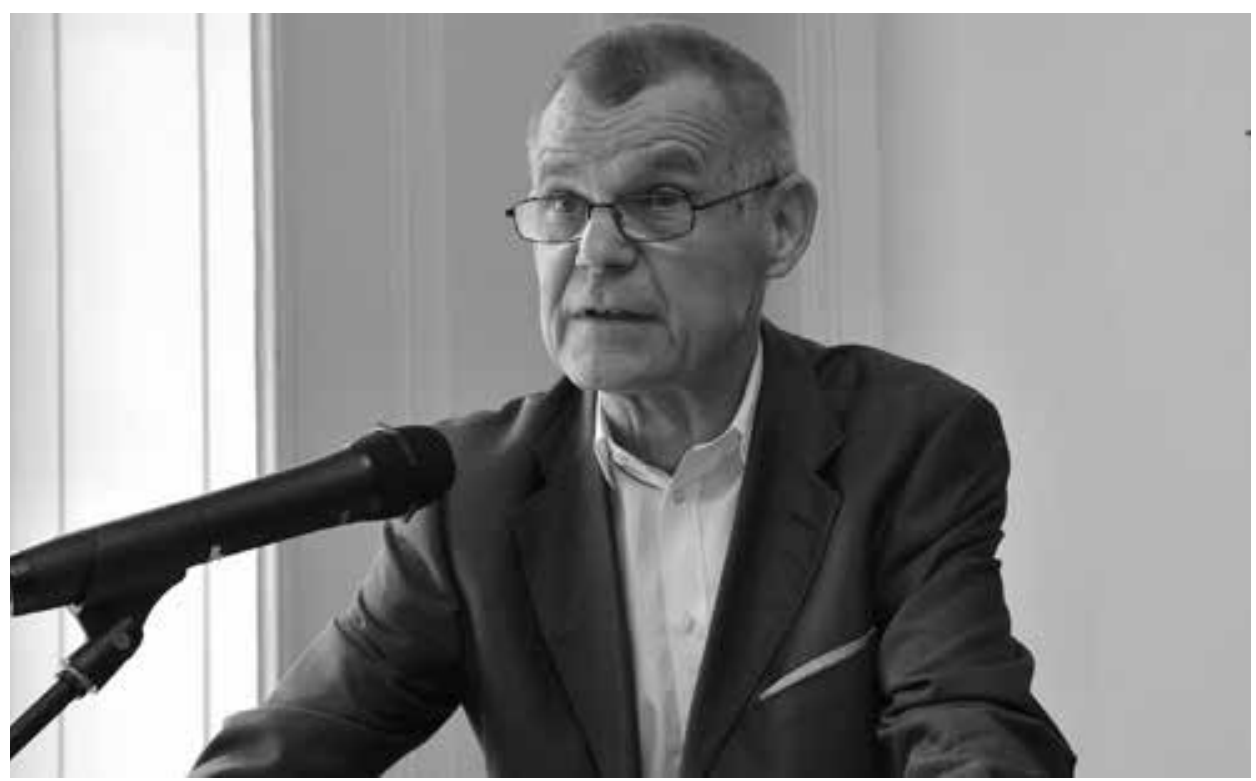

Zbigniew Osiński podczas jubileuszu sześćdziesięciolecia „Pamiętnika Teatralnego”, Instytut Sztuki PAN, 2012. Fot. Krzysztof Piłat

Wszystko jednak zmieniło się w 1962, kiedy do Poznania przyjechał Teatr Laboratorium z Akropolis. Po przedstawieniu - dokładnie 19 listopada 1962 w Restauracji Dietetycznej - doszło do rozmowy Osińskiego z Grotowskim. Po niej Osiński regularnie zacznie jeździć do Opola, poznając wewnętrzne sprawy zespołu, obserwując próby, ćwiczenia aktorskie, spektakle... Tak niespodziewanie ukształtował się najważniejszy temat badawczy.

Osiński miał też w Poznaniu swój epizod twórczy. Jak chyba każdy młody człowiek zafascynowany sceną, chciał sprawdzić się w teatrze. W Teatrze Ósmego Dnia wyreżyserował w 1967, jeszcze jako doktorant, Warszawiankę Wyspiańskiego. Był to czas jego ,zainfekowania” Grotowskim, więc od aktorów niewiele młodszych od siebie próbował egzekwować to, co Grotowski od swoich. ${ }^{2}$ Rolę Chłopickiego zagrał wówczas Lech Raczak i od tego czasu stał się liderem Teatru Ósmego Dnia. Jakkolwiek oceniać tę pracę, Raczak powiedział, że „Współpraca ze Zbyszkiem Osińskim [...] uświadomiła paru osobom z tego amatorskiego teatrzyku, że praca w teatrze nad przedstawieniem jest czymś poważniejszym, niż tylko rozrywką." ${ }^{3} \mathrm{O}$ ile wiem, spektakl z Teatrem Ósmego Dnia był jedyną próbą reżyserską Osińskiego.

2 Pracę Zbigniewa Osińskiego w Teatrze Ósmego Dnia szczegółowo opisał Juliusz Tyszka, Teatr Ósmego Dnia - pierwsze dziesięciolecie (1964-1973), Poznań 2005, s. 45-64.

3 Wprowadzenie do...Z Lechem Raczakiem rozmawiają Ewa Obrębowska-Piasecka, Izabela Skórzyńska, Pawet Piasecki, „Poznański Przegląd Teatralny” 1992 nr 4, s. 121. 
Zbigniew Osiński, jak już wspomniałem, realizował się przede wszystkim jako naukowiec. Jego książkowy debiut to Teatr Dionizosa, wydany w 1972. Książka zawiera nieco zmienione fragmenty rozprawy doktorskiej, czyli teksty o Wilamie Horzycy, ale także studia o Konradzie Swinarskim i Jerzym Grotowskim. Ten debiut nie był jednak ani prosty, ani naturalny, bowiem przygotowaną już w 1968 pozycję odrzuciło Wydawnictwo Poznańskie, ponoć dlatego, że jest za mało ,poznańska”. Osiński wspomina, że było to dla niego pewnego rodzaju upokorzenie. ${ }^{4}$ Minęły cztery lata - i książka, w nieco zmienionej formie, ukazała się w krakowskim Wydawnictwie Literackim. We wstępie do Teatru Dionizosa jest autorska deklaracja, którą można chyba uznać za motto Osińskiego na całą jego dalszą drogę naukową: „Książka nie jest zapewne wolna od akcentów emocjonalnych i wartościujących, pomimo, że starałem się przecież o maksymalny obiektywizm". ${ }^{5}$ Bo tak właśnie odczytuję dążenie Osińskiego do precyzji - wszystko, absolutnie wszystko, co się dało, musiało być sprawdzone, opatrzone przypisami, odwołaniami. Erudycja Osińskiego była wręcz przysłowiowa. Ale równocześnie wszystkie jego prace były wyrazem pasji, autentycznej fascynacji zagadnieniami, które są ich przedmiotem. I dla czytelnika było to widoczne. Właściwie pisał tylko o sprawach, które całkowicie go pochłaniały. Horzyca, Radulski, Limanowski i Osterwa, Byrscy, Staniewski i - na innych nieco, specjalnych prawach - Grotowski, byli, także prywatnie, choćby na chwilę, jego autorytetami. Lecz Osiński w tych swoich ,emocjonalnych akcentach" bywał apodyktyczny, narzucał swoje zdanie, nie lubił sprzeciwu, odmiennych zapatrywań. A polemizować było z nim trudno, bo uzbrojony był w pancerz faktów i przypisów. Ale właśnie te jakże ludzkie fascynacje czyniły go dla czytelników, uczniów, przyjaciół (a pewnie i ,wrogów") wiarygodnym i ciekawym.

Gdy ukazał się Teatr Dionizosa, Osiński pracował już od dwóch lat w Zakładzie Teorii Literatury na Uniwersytecie Warszawskim. I z Warszawą zwiąże się już do końca życia. W rozmowie z Marylą Zielińską powiedział, że Teatr Dionizo$s a$ był „zamknięciem [...] młodości i wejściem w dojrzałość”. ${ }^{6}$ Równocześnie ten tom utorował mu w pewnej mierze drogę na stanowisko kierownika literackiego w Starym Teatrze w Krakowie. Pracował tam, dojeżdżając z Warszawy, w latach 1973-1977 i chyba nie trzeba przypominać, że był to złoty okres tej podwawelskiej sceny. Osiński mógł oglądać najlepsze w Polsce przedstawienia Swinarskiego, Wajdy, Jarockiego. Paradoksalnie jednak jego zainteresowania pozostały niezmienne - to Grotowski zaprzątać będzie go w największym stopniu. Fascynować go będzie także teoria teatru. A Stary Teatr... też go interesował, ale nie poświęcił mu żadnej swojej książki.

\footnotetext{
Z. Osiński, Spotkania z Jerzym Grotowskim. Notatki, listy, studium, Gdańsk 2013.

Idem, Teatr Dionizosa. Romantyzm w polskim teatrze wspótczesnym, Kraków 1972, s. 10.

6 Przecieranie tras (Ze Zbigniewem Osińskim rozmawia Maryla Zielińska), „Nowe Książki” $1999 \mathrm{nr} 6$, s. 6.
} 


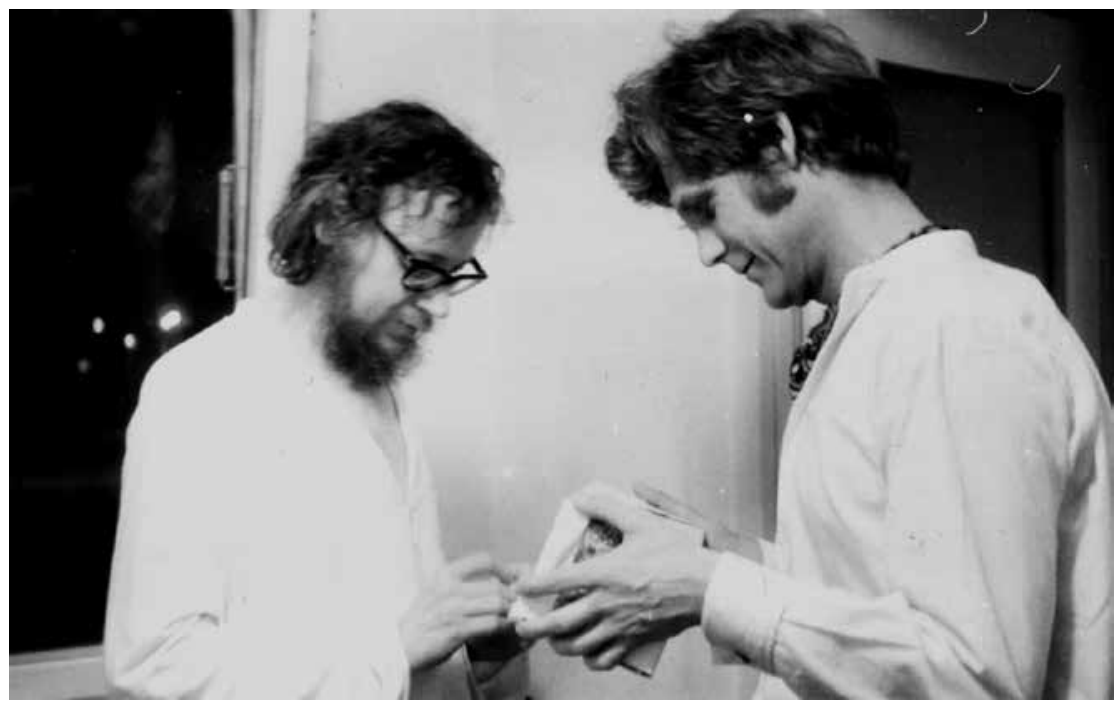

Jerzy Grotowski i Zbigniew Osiński, po habilitacji Osińskiego, 1981. Fot. Maria Kolankiewicz

W 1980 wychodzi książka Zbigniewa Osińskiego Grotowski i jego Laboratorium. ${ }^{7}$ Trafiła doskonale w swój czas - wydana została w momencie, gdy Grotowski był twórcą powszechnie znanym. Mistrzowsko napisana, pełna faktów, danych, udokumentowana z maksymalistyczną precyzją. Ale przede wszystkim, jak to sam autor określił - monografia. Przy następnych swoich publikacjach już nigdy nie użyje takiego sformułowania. Doszedł do wniosku, że tworzenie monografii jest w dzisiejszych czasach niemożliwe. Oczywiście traktował to jako wyraz zmian w humanistyce, zmian w otaczającej rzeczywistości, zmian w jego rozumieniu świata i siebie.

Ale jak określić kolejne książki Profesora? Rzeczywiście, nie pojawi się już monografia na kształt Grotowskiego i jego Laboratorium, ale powstawać będą swoiste monografie otwarte. ${ }^{8}$ Monografie tematów. Książki bardzo precyzyjne

7 Z. Osiński, Grotowski i jego Laboratorium, Warszawa 1980. Książka powstała na podstawie rozprawy habilitacyjnej „Teatr Laboratorium Jerzego Grotowskiego. Historia i światopogląd”.

8 Osiński poświęcił Grotowskiemu w części lub w całości następujące książki: Teatr Dionizosa, op. cit.; Laboratorium Grotowskiego, Warszawa 1978 (książka napisana wspólnie z Tadeuszem Burzyńskim); Grotowski i jego Laboratorium, op. cit.; Grotowski wytycza trasy, Warszawa 1993; Teatr 13 Rzędów i Teatr Laboratorium 13 Rzędów. Opole 1959-1964, Opole 1997; Grotowski. Źródła, inspiracje, konteksty, Gdańsk 1998; Pamięć Reduty. Osterwa, Limanowski, Grotowski, Gdańsk 2003; Nazywat nas bratnim teatrem. Przyjaźń artystyczna Ireny i Tadeusza Byrskich z Jerzym Grotowskim, Gdańsk 2005; Polskie kontakty teatralne z Orientem w XX wieku, Gdańsk 2008; Jerzy Grotowski. Źródta, inspiracje, konteksty: t. 1, wyd. II zmienione, Gdańsk 2009, t. 2, Prace z lat 1999-2009, Gdańsk 2015; Spotkania z Jerzym Grotowskim, op. cit. Do tego spisu można dołączyć jeszcze liczne książki ukazujące się za granicą, które były bądź tłumaczeniami jego polskich publikacji, bądź kompilacjami tekstów, niekiedy mocno zmienionych. 
i szczegółowe - lecz odnoszące się do różnorakich problemów, a nie całości. Grotowski pozostanie wciąż najważniejszym tematem badawczym, ale teraz Osiński będzie pisał o poszczególnych zagadnieniach - Grotowski wobec Orientu, Grotowski i Byrscy, Grotowski i Reduta, młodość Grotowskiego etc. Jakby wciąż, z różnych końców zbliżał się do centralnego punktu, i jeszcze raz, i jeszcze raz, próbując opisać Grotowskiego ze wszystkich stron. Ale ta otwartość działała i w drugą stronę - jego pola badawcze stawały się coraz szersze. Tematy powiązane z Grotowskim pęczniały i zyskiwały samodzielność.

Gdy Osiński opublikował monumentalny tom Pamięć Reduty, napisał znamienne słowa:

Jeśli ktoś zechce nazwać monografią udostępniony w tej książce rezultat poszukiwań, to dobrze. $\mathrm{Z}$ tym że ma to być z założenia monografia otwarta, nie tylko na uzupełnienia, korekty, polemiki, ale również na autokorekty, czyli polemikę z samym sobą z wczoraj, a także dzisiaj. ${ }^{9}$

\section{2.}

Wróćmy jednak do tej pierwszej monografii Teatru Laboratorium... Książka ukazała się w szczęśliwym, jak wspomniałem, momencie - gdy Grotowski był powszechnie znany, a zarazem jego kariera teatralna była już zamknięta, a więc można było opowiedzieć o całości. Autor podążał - jak to w monografii - za prądem lat. Lecz napotkał na pewien problem - po roku 1970 u Grotowskiego wiele się zmieniło i Osiński jako monograf przestał być (aż do 1977) bezpośrednim świadkiem (uczestnikiem) pracy Teatru Laboratorium. Grotowski rozpoczął wtedy okres parateatralny. Gdy Osiński pracował nad monografią, parateatr znał więc tylko z relacji innych i wypowiedzi programowych samego Grotowskiego. Ale gdy nadarzyła się wreszcie okazja, natychmiast sam wkroczył także i na drogę działań czynnych. Jak na odważnego badacza przystało, bez wahania podążył za swoim „przedmiotem badań”. Teatr Laboratorium w latach 1976-1977 realizował Przedsięwzięcie Góra, którego zwieńczeniem był projekt Góra Płomienia (16 lipca-2 sierpnia 1977). I w tych działaniach Zbigniew Osiński uczestniczył. W swojej książce nie pisał o tym doświadczeniu w pierwszej osobie - tam pozostawił tylko suche fakty i opisy innych. Odważył się na tekst o swoich parateatralnych doświadczeniach dopiero po latach.

Zamek Grodziec stał się ową tytułową Górą. Nieustannie przez dni i noce trwały w nim działania parateatralne. Każdego dnia kolejne kilku-, kilkunastoosobowe grupy wyruszały w kierunku Góry Płomienia, wędrując czasem dobę, czasem kilka. Droga miała być okresem odwarunkowania, oczyszczenia zmysłów. Na górę dochodzili kolejni ludzie, inni z niej schodzili - i Święto nieustannie trwało (w Górze Płomienia wzięło udział 120 osób). Osiński opisuje swoje doświadczenia - jak to on - bardzo precyzyjnie i skrupulatnie. Ale i chyba z pewną bezradnością:

\footnotetext{
9 Z. Osiński, Pamięć Reduty, op. cit., s. 19.
} 
Jedną z konstytutywnych cech tego doświadczenia była jego jednorazowość i niepowtarzalność. Kiedy opisuje się jakiś spektakl teatralny, poszukuje się jakichś stałych, tzw. „inwariantów”, bez których dane dzieło nie byłoby po prostu sobą, tracąc swoją tożsamość. Natomiast w przypadku doświadczeń parateatralnych byłoby to zupełnie chybione. Na przykład właściwością Góry Ptomienia była nie tylko jej jednorazowość i niepowtarzalność, lecz i to, że nie było tam spraw bardziej i mniej ważnych: sprzątanie sali, noszenie drewna, wspólne trzepanie kocy, podtrzymywanie ognia, mycie się, posiłki, sen i odpoczynek - wszystko to było ważne i miało jakiś sens. ${ }^{10}$

Zbigniew Osiński w tej swojej opowieści zawarł jeszcze jedno, niezwykle zaskakujące zdanie. Sam był badaczem bardzo skrupulatnym, notował wszystko, gromadził najdrobniejsze dokumenty i fakty, precyzyjnie, erudycyjnie analizował. Jego badania naukowe zawsze zmierzały do niemożliwej obiektywizacji. Jednak po Górze Płomienia napisał: „Być może niektórzy spośród tych, którzy potrafili zachować to doświadczenie dla siebie i nie rozmienili go na drobne w opowieściach, przyjęli z niego najwięcej”. ${ }^{11}$ Jak można przypuszczać, udział w nim do pewnego stopnia przewartościował to, czym jest rola naukowca, badacza i krytyka. Bo domyślam się, że w Osińskim coś wtedy się przełamało. Stał się badaczem w drodze. Ale w drodze szczególnej - nie tylko po archiwach, konferencjach, spektaklach (choć to wszystko pozostało). To parateatralne ukąszenie w dużym stopniu uczyniło z niego także ,uczestnika”. Wnikliwość i erudycja łączyć się $\mathrm{w}$ nim będą $\mathrm{z}$ pasją uczestniczenia $\mathrm{w}$ działaniach na pograniczu teatru.

Powszechnie uważamy, że pisanie wspomnień o kimś, kto niedawno zmarł, jest najczęściej pisaniem o sobie. Nie inaczej jest i w tym moim wspomnieniu. Wybieram bowiem fakty z jego życia, które tworzą „,mojego Osińskiego”. Teraz pozwolę sobie na kilka jeszcze bardziej osobistych dopowiedzeń.

Gdy powstawały Gardzienice (1977), Osiński od początku bardzo kibicował Staniewskiemu i jego grupie, jeździł na Wyprawy i do Gardzienic. Pisał o nich. I nieświadomie zapewne stanął $\mathrm{u}$ początku moich fascynacji teatralnych. Bowiem jeden z jego tekstów - w „Radarze”"12, będąc jeszcze w szkole średniej, przeczytałem. Po lekturze napisałem do Gardzienic - i zostałem zaproszony. Gardzienice żyły wtedy bardzo skromnie. A i świat był nieco inny - dotrzeć do Gardzienic było trudno. Jechało się autobusem do Piask, a stamtąd - ze trzy kilometry z okładem trzeba było przejść pieszo. Przyjechałem trochę wcześniej, a z autobusu w Piaskach wysiadł też pan z plecakiem. I szybko zagadnął mnie; okazało się, że idziemy do Gardzienic. „Zbyszek” - przedstawił się. „Tadeusz” - odpowiedziałem, w ogóle nie przypuszczając, że to Osiński. Dzisiaj wiem, że wiele osób przez całe życie nie mówiło z Panem Profesorem po imieniu, ja natomiast nigdy nie byłem z nim na „Pan”. To może drobiazg, ale takiego Zbyszka pamiętam, a i on tę anegdotę opowiadał.

10 Z. Osiński, Notatki z „,Góry Płomienia”, lipiec 1977. Spisane po doświadczeniu, „Pamiętnik Teatralny" 2001 z. 1-2, s. 212.

11 Ibidem, s. 213.

12 Z. Osiński, Gardzienice - więcej niż teatr, „Radar” 1979 nr 12. 


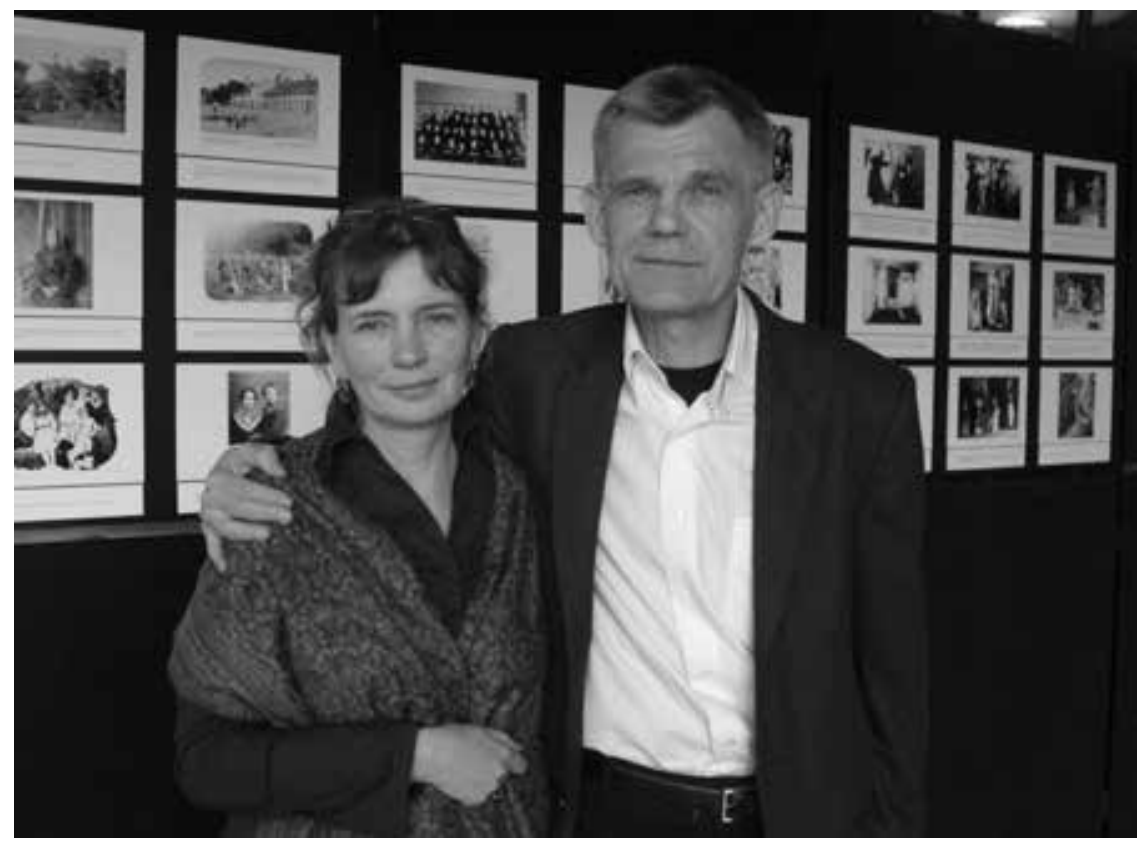

Katarzyna i Zbigniew Osińscy na tle wystawy poświęconej Kantorowi, Moskwa 2005. Fot. W. Łupowskoj

Kilkanaście lat później zacząłem pisać u niego pracę doktorską o Gardzienicach (po dwóch latach, w związku z moją afiliacją przy UJ musiałem zmienić promotora). Nasza znajomość, momentami nawet coś na kształt przyjaźni (często zrywanej), trwała właściwie do końca jego życia. Spotykaliśmy się w najbardziej zaskakujących miejscach - w Węgajtach, Sejnach, Holstebro, na Wyprawach i festiwalach, konferencjach, w Ośrodku Grotowskiego, a w ostatnich latach jego życia w Rzeszowie, corocznie podczas festiwalu „Źródła Pamięci. Szajna - Kantor Grotowski”. Pisaliśmy do siebie, lecz wyłącznie o teatrze. I dopiero w Rzeszowie rozmawiałem z Osińskim godzinami - o świecie, religii, polityce i wielu innych sprawach. Coraz mniej o teatrze. Podziwiałem Profesora - był dla mnie wielkim autorytetem. Nadużyciem byłoby, gdybym nazwał się jego uczniem, ale na pewno darzyłem go przyjaźnią i śmiem przypuszczać, że z wzajemnością.

Ośrodek Praktyk Teatralnych Gardzienice był dla Osińskiego bardzo istotnym projektem badawczym. Pierwsze poważne i obszerne teksty o tym zespole pisał właśnie on (oczywiście nie tylko on, bo także Leszek Kolankiewicz, Halina Filipowicz i inni). Znów został zmuszony - a raczej wszedł w to z radością - do wędrowania, do Wypraw, bo tym zajmował się kolejny jego „przedmiot badań” - Gardzienice. Staniewski szukał na wsi nowego naturalnego środowiska teatru, odwoływał się do romantyzmu, do Limanowskiego, wyszedł na dodatek z Laboratorium - wszystko to fascynowało Osińskiego. 
Grotowski po wprowadzeniu stanu wojennego wyjechał z Polski do Stanów Zjednoczonych, potem do Włoch. Właściwie z naszej perspektywy niewiele było wiadomo o jego pracy. W spotkaniach Osińskiego z Grotowskim też jest istotna luka między rokiem 1982 a 1988. Praca naukowca nie cierpi pustki - więc wszedł tu z pełną siłą Radulski, Osterwa i Limanowski, i... Staniewski. Gardzienice to prawdziwa jego pasja. Powstają niezwykle ciekawe teksty - właściwie ustanawiające krytyczną recepcję Gardzienic. ${ }^{13}$ Osiński jeździ na Wyprawy, pisze, rozmawia, wprost mówi o fascynacji. A później coś się w nim zacięło. Do dzisiaj nie umiem sobie tego wytłumaczyć. Osiński porzucił Gardzienice, cały ten obszar swoich badań. Można domniemywać, że zostawił to pole badawcze późniejszym autorom książek i tekstów o Gardzienicach - Zbigniewowi Taranience, Ireneuszowi Guszpitowi i innym. W pewnym momencie nawet przypuszczałem nieskromnie, że odstąpił ten temat właśnie mnie - bo zacząłem u niego pisać doktorat, ale tak nie było. Wiem, że była to naprawdę wielka jego fascynacja i nadzieja, ale porzucona. Dlaczego - nie potrafię odpowiedzieć. Grotowski pozostał jego pasją na całe życie, Staniewski tylko na stosunkowo krótki czas.

Po latach pisał o Gardzienicach, że był to zespół, który dał najmocniejszą artystyczną odpowiedź na swoje czasy. Gdy byłem redaktorem w „Didaskaliach”, spróbowałem go namówić na publikację zapisków z Wyprawy, o których opowiadał. Zrobił więcej - napisał też komentarze do swoich notatek. Na koniec stwierdził:

Gardzienice są w ciągłym procesie rozwoju. W porównaniu z nimi mam poczucie, jakbym się gdzieś zatrzymał wraz z całą moją wiedzą i pracą uniwersytecką. To jest właśnie podstawowa różnica między bezpośrednim doświadczaniem, a teorią. [...] Jednak na dłuższy dystans ta druga ma również swoje przewagi: pozwala być samodzielnym i niezależnym (choć również i bardziej samotnym), nie działa jak narkotyk, ale też nie uzależnia od grupy [...] Mój problem: nie dać się zjeść grupie i przywódcy, w każdych warunkach zachować niezbędne minimum swojej autonomii i niezależności. ${ }^{14}$

To przełamanie, ta „samotność”, będzie konsekwentnie znaczyła jego działalność naukową. Osiński będzie nadal z uwagą podążał za różnymi inicjatywami usytuowanymi na obrzeżach teatru i kultury czynnej, ale już chyba zawsze i wyłącznie z perspektywy honorowego gościa, autorytetu, naukowca, badacza...

Zamiast więc wyczekiwanej przeze mnie książki Zbigniewa Osińskiego o Gardzienicach, ukazała się kolejna o Grotowskim - Grotowski wytycza trasy. Została wydana w 1993, trzynaście lat po poprzedniej jego autorskiej książce na ten temat. Znów była to niezwykle ważna i oczekiwana lektura. Opowiadała między

13 Najważniejsze teksty Osińskiego o Gardzienicach to: Gardzienice. Praktykowanie humanistyki, [w:] Sztuka otwarta. Parateatr II, red. E. Dawidejt-Jastrzębska, Wrocław 1982; ,, Gusta”. Krótki opis (nie zapis) spektaklu, „Dialog” $1983 \mathrm{nr}$ 2; Wyprawa włoska, „Dialog” $1983 \mathrm{nr} 2$; Uwagi o Gardzienicach, „Dialog” $1983 \mathrm{nr} 2$.

14 Z. Osiński, Notatki z Wyprawy „,Gardzienic”: 1-6 czerwca 1983. Po szesnastu latach, „Didaskalia" $1999 \mathrm{nr}$ 30, s. 71. 


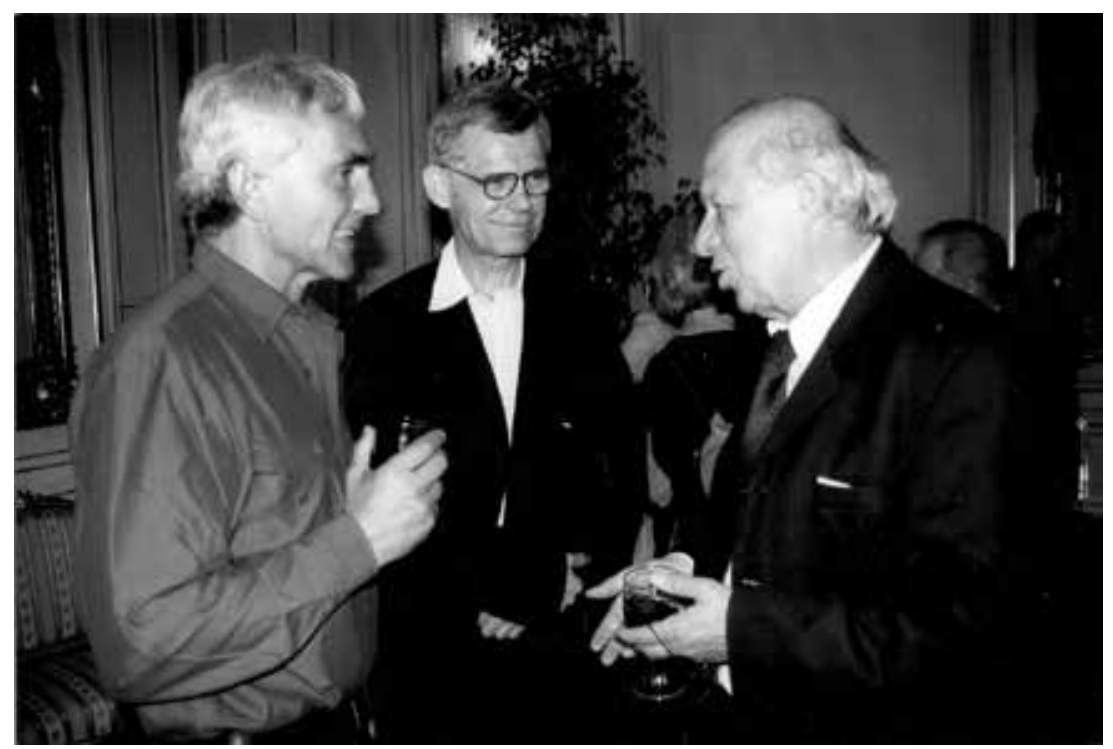

Uroczystość nadania Eugenio Barbie doktoratu honoris causa Uniwersytetu Warszawskiego, 2003.

Od lewej: Eugenio Barba, Zbigniew Osiński, Jerzy Gurawski. Fot. Katarzyna Osińska

innymi o Grotowskim po jego wyjeździe z Polski. Osiński był jednym z pierwszych świadczących o pracy w Pontederze. Jerzy Grotowski zaczął wtedy pracować w dziedzinie - jak to nazwał - sztuki jako wehikułu. Powstała Akcja - czyli widowisko podobne do sztuki teatru, ale nie przeznaczone do oglądania. Było dla tych, którzy działają. Tylko wyjątkowo w pierwszym okresie Grotowski zapraszał „widzów”, czy lepiej powiedzieć - świadków tej pracy. Była to więc książka niezwykle istotna, bo Grotowski naprawdę na ponad dekadę zniknął z pola badań teatrologicznych w Polsce. Dochodziły tylko pogłoski, że pracował w Irvine, że przeniósł się do Włoch... Dzisiaj w ogóle trudno sobie to wyobrazić, ale wiedza o jego dokonaniach zagranicznych była w latach osiemdziesiątych nadzwyczaj skromna. Z polskiej perspektywy wydawało się, że całkiem zniknął z teatralnego pola. Książka Osińskiego była jak łyk świeżej wody dla tych, którzy byli ciekawi Grotowskiego i jego pracy.

Zbigniew Osiński nigdy nie przerwał kontaktu z Grotowskim - korespondował z nim, rozmawiał. W 1989 przygotował w Polsce zbiór pism Grotowskiego Teksty z lat 1965-1969, w drugim wydaniu poszerzony o tekst Performer - dotyczący już najnowszej pracy. ${ }^{15}$

15 Grotowski nie chciał wtedy, by ukazała się po polsku jego książka Ku teatrowi ubogiemu, ale niektóre zawarte w niej teksty pozostały dla niego ważne. Do pierwszego wyboru dodano kilka innych tekstów i tak powstała pozycja: J. Grotowski, Teksty z lat 1965-1969. Wybór, wybór i red. J. Degler, Z. Osiński, Wrocław 1989, wyd. 2. poprawione i uzupełnione, Wrocław 1990. 
W tym miejscu muszę przyznać, że ogromnie lubiłem czytać Osińskiego, odpowiadał mi jego język i sposób pisania o Grotowskim (i nie tylko o Grotowskim). Starał się być „obiektywny”, ze świadomością, że coś takiego w teatrologii nie istnieje. Ale usiłował. Wszystko było konkretne, jak kamienie, z których buduje się konstrukcję domu. Pisał o Grotowskim jak polonista ze szkoły Szweykowskiego. I to jest komplement. Każdy detal, każde słowo Grotowskiego było wskazówką, która opisywana była w skali 1:1 - „obiektywnie”, naukowo. Niekiedy sztywno, jak z punktu widzenia belfra. Niekiedy nieatrakcyjnie. Czasem fascynująco. Grotowski mówił, że wszystko w jego pracy jest sprawą czynienia - a Osiński, także z powodu ograniczeń wokalnych i cielesnych - nie mógł uczestniczyć w pracy nad sztuką jako wehikułem i nie był do niej zaproszony. Ale opisywał ją jak rasowy badacz - bardzo klarownie i zapewne klarowniej niż jej uczestnicy.

\section{3.}

Zbigniew Osiński był niezwykle skrupulatnym badaczem bibliotek i archiwów. Myślę, że wszystkie najważniejsze zbiory, zawierające materiały dotyczące tematów, które go interesowały, zostały spenetrowane do końca. Gdy Osiński badał twórczość Horzycy, Grotowskiego, Osterwy, Byrskich czy Radulskiego, był gotowy pojechać choćby na koniec świata i spędzić godziny w archiwach, by wydobyć wszelkie informacje. Uwielbiał zestawienia - choćby twórczości Swinarskiego czy właściwie kronikę dzienną Grotowskiego. Uważał, że takie fakty są istotne, mają podstawowe znaczenie i tylko dzięki ich znajomości można budować konstrukcję opisującą dane zjawisko. Ale - o czym wie może niewielu ta faktografia miała i drugie dno. Kiedyś napisałem recenzję książki Osińskiego o Reducie. ${ }^{16}$ Podziękował za nią i - jak to w jego stylu - wskazał mi, co należałoby w niej rozszerzyć, a co jest zbyteczne. Lecz najbardziej ujęło go to, co napisałem o zestawieniu w jego książce możliwie pełnej listy nazwisk członków Reduty, że jest jak apel poległych, jak wydobywanie ich z niebytu. O tym rozmawialiśmy - i powiedział, że to było rzeczywiście jego zamiarem, jego celem. Że z zewnątrz może wydawać się, że chodzi o perfekcję, ale tak naprawdę chodzi o pamięć, o jej ocalenie i o tych ludzi. Że zostaje jakiś ślad. Że Reduta to nie tylko Osterwa i Limanowski, ale też wielu aktorów, adeptów, współpracowników. Jego pedanteria jako historyka teatru odsłoniła w tej rozmowie ważny aspekt: zajmowanie się historią teatru to nie tylko kolekcjonowanie faktów, ale też wspominanie ludzkich istnień, ludzi, którzy nie żyli na darmo. Osiński przez ponad czterdzieści lat badał zjawisko zwane Redutą. Najpierw z naukowym dystansem, później z coraz większą fascynacją. Edytował teksty, korespondencję... W Pamięci Reduty, mimo nieustannego zakorzeniania każdej myśli w faktach, mimo przytaczania obszernych cytatów innych badaczy i wypisów z różnorakich dokumentów, tę autorską pasję widać bardzo wyraźnie. Praca nad książką stawała się pracą nad własną

\footnotetext{
16 T. Kornaś, Drabina Reduty, [w:] idem, Aniołom i światu widowisko, Kraków 2009.
} 
osobowością, nad poszukiwaniem sensu. To nie przypadek, że piszę w ten sposób o Osińskim, bo jego pisanie było dążeniem do perfekcji. Jak Grotowski mówił o drabinie Jakubowej, że najważniejsze jest, by była dobrze, solidnie zbudowana, tak gdy myślę o Osińskim, wydaje mi się, że to było też jego założenie w pracy naukowej.

Jerzy Grotowski miał szczęście, bo spotkał na swojej drodze wielu opisywaczy, partnerów. Teksty o Grotowskim można liczyć na tysiące. W latach osiemdziesiątych, dziewięćdziesiątych, dwutysięcznych czytałem wszystko, co się dało. U nas w Polsce byli dwaj ważni autorzy piszący o Grotowskim - Zbigniew Osiński i Leszek Kolankiewicz. Obaj pracowali w Katedrze Kultury Uniwersytetu Warszawskiego. Dla mnie obaj byli autorytetami, ale ich teksty były krańcowo różne. Dziś widać - jak bardzo komplementarne.

Jak wspomniałem wcześniej, poznałem też Zbigniewa Osińskiego jako pedagoga. ${ }^{17}$ Zacząłem u niego pisać doktorat o Gardzienicach i chodziłem na seminarium $^{18}$, w którym brali udział zarówno jego magistranci, jak i doktoranci. Było to jedno z najmocniej formujących mnie doświadczeń. Osiński wymagał od studentów tyle, ile od siebie. Co więcej, wiele swoich fascynacji przenosił na studentów. W tamtym czasie kilku jego magistrantów siedziało w archiwach, odczytując na przykład notatki Limanowskiego, czy jeździło do Francji, by badać dziedzictwo Copeau. Wydaje mi się, że sposób pracy Osińskiego ze studentami dokładnie odwzorowywał jego własny charakter badawczy.

Siłą Osińskiego była umiejętność schowania się za opisem, bycia świadkiem, „sługą” sprawy. Oczywiście, wszyscy, którzy go znali stosunkowo blisko, wiedzą, że był wielkim egotykiem - lecz w przedziwny, systematyczny sposób potrafił ukryć swoje ego za materią słowa. Osiński potrafił też być apodyktyczny. A równocześnie wydawało się, że Grotowskiemu poświęcił większość swojego życia naukowego. Niekiedy wręcz odnosiło się wrażenie, że przesadza w swojej „,wierności" Grotowskiemu.

W ostatniej książce Osiński zamieścił korespondencję z Grotowskim, a dokładniej - listy Grotowskiego. Pomimo ciepłego tonu niektórych z nich, trudno odnieść wrażenie, by łączyła ich głęboka przyjaźń. Może to będzie trywialne stwierdzenie, może niesprawiedliwe, ale momentami przy ich lekturze rodziło się wrażenie, że Grotowski wykorzystywał Osińskiego. A na dodatek Osiński to odczuwał i przyjmował. Osiński był potrzebny Grotowskiemu. Ale była i druga strona. Dla Osińskiego Grotowski i jego dzieło to był przedmiot badań. Najbardziej fascynujący w jego życiu. Niepotrzebna była tu więź głębokiej przyjaźni. To wielki paradoks, ale moim zdaniem, wierność Osińskiego wobec Grotowskiego była przede wszystkim wiernością wobec siebie, wobec swojej postawy i pracy

17 Zbigniew Osiński w 1991 został profesorem UW, w 1996 profesorem nadzwyczajnym, a w 2000 otrzymał tytuł profesora zwyczajnego.

18 Ostatecznie mój doktorat powstał na Uniwersytecie Jagiellońskim pod opieką prof. dr hab. Małgorzaty Sugiery. 


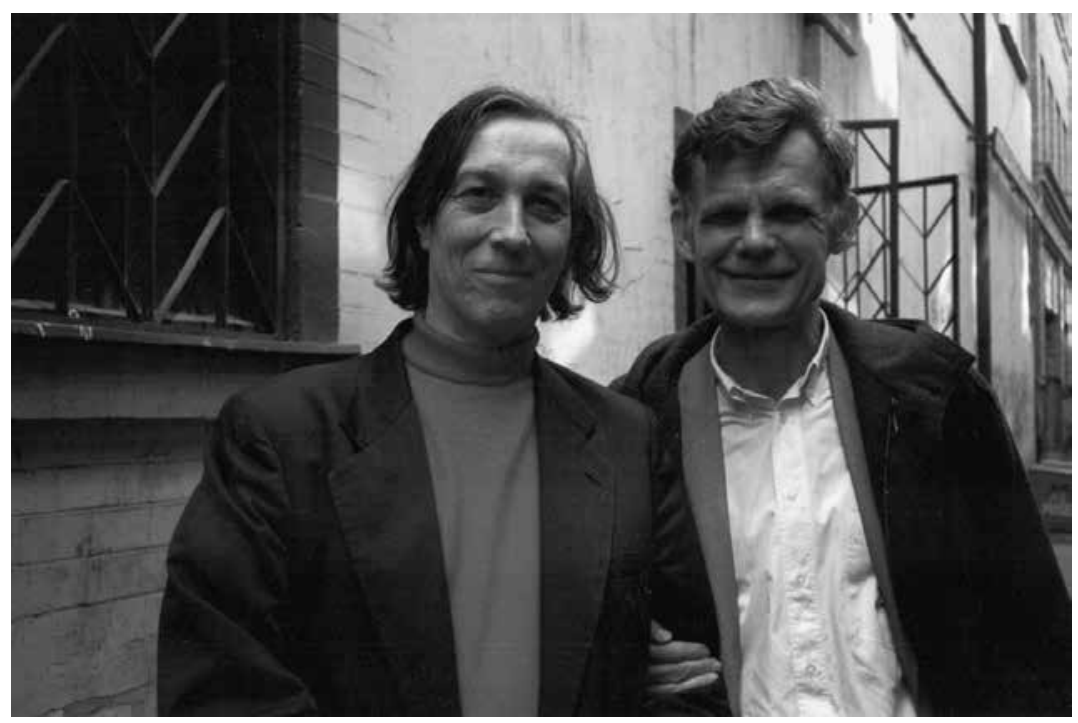

Zbigniew Osiński i Lech Raczak. Fot. Katarzyna Osińska

badawczej, naukowej, którą Osiński zogniskował wokół artysty i jego dzieła. I chyba w tej relacji między nimi nie było fałszu. I chyba obaj zdawali sobie sprawę z tego, że są sobie potrzebni. Osiński w ostatniej swojej książce napisał:

relacja między tak zwanym badaczem a tak zwanym praktykiem jest $w$ istocie dużo bardziej złożona, niż zazwyczaj się uważa, i wcale nie musi być relacją jednostronnego podporządkowania. Twierdzę nawet, że relacja polegająca tylko na podporządkowaniu badacza teatrowi prędzej czy później musi się okazać jałowa. Jedynie relacja dialogowa między nimi może mieć jakąś wartość. ${ }^{19}$

4.

Osiński, obok pisania o teatrze, miał też misję. Był pomysłodawcą - razem z Tadeuszem Burzyńskim, Józefem Kelerą i Januszem Deglerem - utworzenia Ośrodka Grotowskiego we Wrocławiu. Jak sam wspomina, powiedział o tym po raz pierwszy Grotowskiemu w sobotę, 30 kwietnia 1988. Stwierdził, ,że jest to sprawa, której warto byłoby spróbować poświęcić resztę życia". ${ }^{20}$ Oczywiście chodziło o życie Osińskiego, nie Grotowskiego. Po latach Zbigniew Osiński wspominał, że było to jednak pochopne stwierdzenie, ale tylko dzięki takiej determinacji udało się mu powołać Ośrodek Badań Twórczości Jerzego Grotowskiego i Poszukiwań Teatralno-Kulturowych we Wrocławiu. Osiński będzie jego pierwszym dyrektorem naukowym i artystycznym. Rozpocznie od przeglądu archiwum,

19 Z. Osiński, Spotkania z Jerzym Grotowskim, op. cit., s. 282-283.

20 Ibidem, s. 103. 


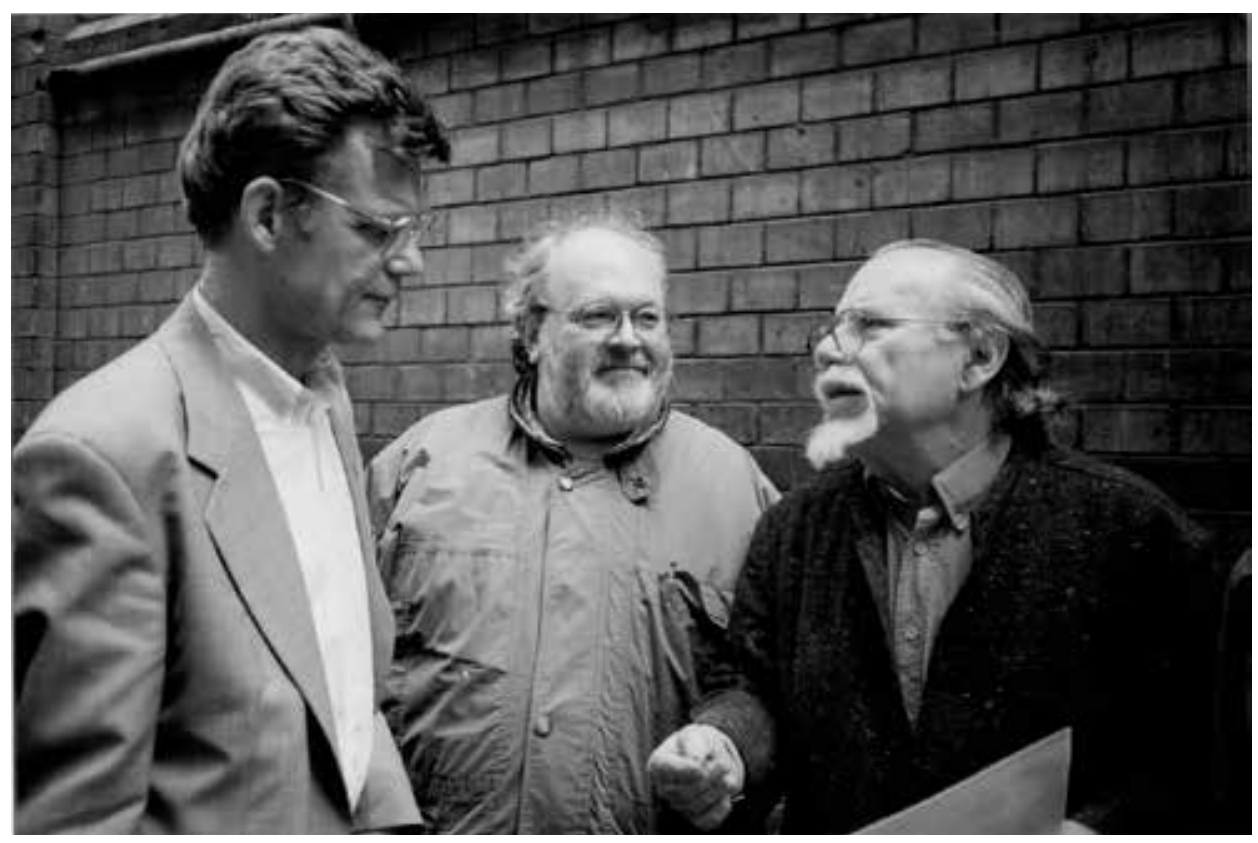

Podczas sympozjum „Laboratoria teatralne i teatry studyjne w Europie - XX wiek.

Techniki i wartości. Rekonesans”, dedykowanego pamięci Konstantego Puzyny i Fabrizia Crucianiego, Wrocław 1997. Od lewej: Zbigniew Osiński, Niola Savarese i Ludwik Flaszen.

Fot. Katarzyna Osińska

pojawią się ważne projekty kulturowe. Dzisiaj, po wielu przekształceniach, także zmianie nazwy - Instytut im. Jerzego Grotowskiego jest wciąż jedną z najważniejszych instytucji kulturalnych w Polsce. Znów można powiedzieć, że powstał dzięki Osińskiemu, choć w dużej mierze zmienił teraz charakter. Osiński bowiem starał się być maksymalnie uczciwy wobec Grotowskiego. Za jego kierownictwa w Ośrodku - zgodnie z umową z Grotowskim - nie mogło być żadnego zespołu artystycznego, nie miało to być także miejsce macierzyste dla warsztatów byłych aktorów Grotowskiego, bądź jego współpracowników z okresu parateatralnego czy Teatru Źródeł. Dopiero, gdy Osiński odejdzie, ta sytuacja się zmieni.

Ale przyznać trzeba, że to pod dyrekcją Osińskiego (przy wsparciu Deglera, Kelery i Burzyńskiego) ośrodek stał się miejscem niezwykle ważnym na mapie kraju. Na dodatek mającym ogromne znaczenie edukacyjne i kulturowe. W specyficzny sposób kształtujące sposób patrzenia wielu osób na teatr i kulturę. Oddam głos późniejszemu dyrektorowi programowemu, Grzegorzowi Ziółkowskiemu:

Szereg spotkań warsztatowych, wykładów, seminariów, promocji książek, prezentacji filmowych wraz z otaczającą je aurą ważności i jedyności, w których dane mi było uczestniczyć [...] stanowiły dla mnie alternatywną szkołę teatru i kultury. Z czasem to, co uzupełniać miało moje wykształcenie, stało się jego esencją. Tutaj, podczas spotkania z Peterem Brookiem, ugruntowała się 
moja fascynacja jego twórczością i osobowością, tutaj uczyłem się podstawowych ćwiczeń mimu od ucznia Decroux - Thomasa Leabharta, a od Zygmunta Molika - podstaw warsztatu Laboratorium, tutaj obejrzałem przedstawienia Odin Teatret i teatru Wasiljewa [...]. Tu nabierałem przekonania, iż kultura jest jak powietrze, którym się oddycha. ${ }^{21}$

Osiński kierował Ośrodkiem mądrze. Zaczął robić to, co najważniejsze - porządkować archiwum. Następnie zapraszać osoby bliskie Grotowskiemu - Brooka, Wasiljewa, Barbę... Organizować konferencje. Starał się być wierny Grotowskie$\mathrm{mu}$ - a więc nie robić z Ośrodka miejsca staży i zatrudnienia jego współpracowników, jednak z drugiej strony utrzymywał z nimi bliski kontakt i chętnie gościł ich w Ośrodku. Zbigniew Osiński posiadał umiejętność zarażania swoimi pasjami. Gdy organizował jakąś imprezę, miało to być na najwyższym światowym poziomie. I co ciekawe, większość prezentacji i konferencji Ośrodka Badań Twórczości Jerzego Grotowskiego i Poszukiwań Teatralno-Kulturowych łączyła się z jego osobistymi pasjami.

5.

To moje wspomnienie dotyczy tylko niewielkiej części dokonań Zbigniewa Osińskiego. Pewnie powinienem więcej napisać o jego pozostałych pasjach badawczych, książkach autorskich i edytowanych przez niego. O teatrze orientalnym, teatrze studenckim, o Limanowskim, Byrskich, Odin Teatret, Meyerholdzie i wielu, wielu innych sprawach. Osiński pisał bowiem dużo i bardzo precyzyjnie. Opublikował wiele fundamentalnych tekstów. Na przykład gdyby zebrać jego artykuły i opracowania materiałów, listów, mogłaby powstać gotowa, bardzo potrzebna książka o Wacławie Radulskim...

Myślę, że praca Zbigniewa Osińskiego domaga się pełnego opisania i... kontynuacji. On sam, pisząc na różne tematy, często wskazywał, co jest do zrobienia. Tych rzeczy do wykonania, rozwinięcia, dopełnienia pozostało sporo. O kontynuację niektórych zadbał, innych - nie zdążył. Osiński chciał być „budowniczym mostów”. Kiedyś powiedział:

Albo więc należymy do już minionej epoki, albo tworzymy jakiś pomost między tym, co było i tym, co będzie. Tak jak wielu osobom, zależy mi, by wyrzeźbić konkretny kształt, by mieć co przekazać do twórczej kontynuacji uczniom, współpracownikom. ${ }^{22}$

21 G. Ziółkowski, Ośrodek, czyli jak złapać pstraga, „Didaskalia” 2001 nr 43-44, s. 60.

22 Przecieranie tras, op. cit., s. 8.

Redakcja bardzo dziękuje Katarzynie Osińskiej za wybór i udostępnienie zdjęć. 